\title{
HUBUNGAN ANTARA STATUS GIZI DENGAN KADAR HEMOGLOBIN PADA REMAJA USIA 12-14 TAHUN
}

\author{
${ }^{1}$ Kevin A. Sompie \\ ${ }^{2}$ Max F. J. Mantik \\ ${ }^{2}$ J. Rompis
${ }^{1}$ Kandidat Skripsi Fakultas Kedokteran Universitas Sam Ratulangi Manado
${ }^{2}$ Bagian Ilmu Kedokteran Anak, Fakultas Kedokteran Universitas Sam Ratulangi Manado
Email: kay.sompie@outlook.com

\begin{abstract}
One of the causes of low hemoglobin is inadequate nutrition. Nutrition obtained from various foods and drinks we consume such as: rice, meat, vegetables, fish, and water. Nutritional intake is one of the determinants of nutritional status can be measured by anthropometric status. This study aimd to find the relationship between hemoglobin levels with daily nutritional status in teen aged 12-14 years with an analytical study design using cross sectional approach. Samples of this study were a part of the population who met the inclusion and exclusion criteria were 45 people. Data collected through anthropometric measurements and measurements of hemoglobin, then analyzed using Pearson Correlation test. The results showed that the nutritional status (BMI/U) that was normal $48.89 \%$, overweight $22.22 \%$, obesity $28.89 \%$, and there was no respondents with malnutrition, while non-anemic $82.2 \%$ and anemic $17.8 \%$. Conclusion: There was no correlation between nutritional status (BMI / U) for hemoglobin levels with a p-value is $0.343>\alpha=0.05$.
\end{abstract}

Keywords: hemoglobin, nutritional status, teen

\begin{abstract}
Abstrak: Salah satu penyebab Hb rendah adalah nutrisi yang inadekuat. Nutrisi didapatkan dari berbagai makanan dan minuman yang biasa kita konsumsi seperti: nasi, daging-daging, sayur-sayuran, ikan, dan air. Asupan gizi adalah salah satu indikator penentu status gizi yang dapat diukur melalui status antropometri. Penelitian ini bertujuan untuk mengetahui hubungan antara kadar hemoglobin dengan status gizi sehari-hari pada remaja usia 12-14 tahun dengan rancangan penelitian bersifat analitik dengan menggunakan pendekatan potong lintang (cross sectional). Sampel dari penelitian ini merupakan bagian dari populasi yang memenuhi kriteria inklusi dan eksklusi berjumlah 45 orang. Data yang dikumpulkan melalui pengukuran antropometri dan pengukuran hemoglobin, kemudian dianalisis dengan menggunakan uji Pearson Correlation. Hasil penelitian memperlihatkan bahwa Status Gizi (IMT/U) yang normal sebesar $48.89 \%$, overweight sebesar $22.22 \%$, obesitas sebesar $28.89 \%$, dan tidak ada responden dengan gizi kurang maupun sangat kurang, sementara nonanemis sebesar $82.2 \%$ dan anemis sebesar 17.8\%. Simpulan: Hasil penelitian ini menyimpulkan bahwa tidak terdapat hubungan antara status gizi (IMT/U) terhadap kadar hemoglobin dengan nilai p yaitu $0.343>\alpha=0.05$.
\end{abstract}

Kata kunci: kadar hemoglobin, remaja, status gizi

Hemoglobin merupakan protein dalam sel darah merah yang mencakup oksigen $\left(\mathrm{O}^{2}\right)$. Hemoglobin dapat meningkat ataupun menurun. Penurunan kadar hemoglobin dalam darah bisa disebabkan oleh banyak faktor diantaranya anemia, perdarahan, penyakit ginjal kronik, leukemia, nutrisi rendah, dan kadar zat besi, asam folat, vitamin B12, atau vitamin B6 yang rendah. ${ }^{1}$ Salah satu penyebab turunnya 
kadar hemoglobin atau yang biasa disingkat dengan $\mathrm{Hb}$ adalah nutrisi yang inadekuat. Nutrisi didapatkan dari berbagai makanan dan minuman yang biasa kita konsumsi seperti: nasi, daging-daging, sayur-sayuran, ikan, dan air.

Anemia merupakan penyakit dimana kadar hemoglobin dalam darah rendah. Anemia defisiensi ialah anemia yang disebabkan oleh kekurangan satu atau beberapa bahan yang diperlukan untuk pematangan eritrosit. Penyakit ini banyak ditemukan diseluruh dunia. Tidak hanya di negeri yang sedang berkembang saja, tetapi juga di negeri yang sudah maju, terutama mengenai anak yang sedang tumbuh. Anemia defisiensi yang paling banyak adalah anemia defisiensi besi. ${ }^{2}$

Menurut WHO tahun 2008, terdapat 1,62 juta penduduk yang menderita anemia. Prevalensi tertinggi ditemukan pada anakanak sebelum usia sekolah sebesar $47.4 \%$. Prevalensi terendah ada pada laki-laki dewasa sebesar $12,7 \%$. Namun, populasi dengan angka kejadian terbanyak ialah wanita yang tidak hamil. ${ }^{3}$

Di Indonesia, prevalensi tertinggi ditemukan pada akhir masa bayi dan awal kanak-kanak diantaranya karena terdapat defisiensi besi saat kehamilan dan percepatan tumbuh masa kanak-kanak yang disertai rendahnya asupan besi dari makanan, atau karena penggunaan susu formula dengan kadar besi kurang. Selain itu, anemia defisiensi besi juga banyak ditemukan pada masa remaja akibat percepatan tumbuh, asupan besi yang tidak adekuat dan diperberat oleh kehilangan darah akibat menstruasi pada remaja puteri. Data SKRT tahun 2007 menunjukan prevalensi anemia defisiensi besi. Angka kejadian anemia defisiensi besi pada anak balita di Indonesia sekitar 40-45\%. Survai Kesehatan Rumah Tangga (SKRT) tahun 2001 menunjukan prevalensi anemia defisiensi besi pada bayi 0-6 bulan, 6-12 bulan, dan anak balita berturut-turut sebesar $61,3 \%, 64,8 \%$, dan $48,1 \%{ }^{4}$

Pada bayi dan anak perlu diberikan makan yang sebaik-baiknya. Tujuannya ialah untuk kebutuhan, memelihara kesehatan dan memulihkannya bila sakit, melaksanakan berbagai jenis aktifitas, pertumbuhan dan perkembangan jasmani serta psikomotor, mendidik kebiasaan yang baik tentang memakan, menyukai, dan menentukan makanan yang diperlukan. ${ }^{2}$

Anak-anak adalah fondasi awalnya perkembangan. Awal masa kehidupan adalah masa yang sangat penting bukan hanya kesehatan pribadi dan pertumbuhan, tetapi juga untuk perkembangan kognitif dan emosi-sosial. ${ }^{5}$ gangguan makan dapat mempengaruhi anak-anak dengan perkembangan normal begitu juga dengan yang mengalami kesulitan terhadap kesehatan maupun faktor pertumbuhan. ${ }^{6,7,8}$

Kebutuhan nutrisi individu bervariasi sesuai dengan perbedaan genetik dan metabolik. Namun untuk bayi dan anak, tujuan dasar adalah pertumbuhan yang memuaskan dan mencegah defisiensi. Nutrisi yang baik membantu mencegah penyakit akut dan kronis dan mengembangkan kemampuan fisik dan mental; nutrisi juga harus memberikan cadangan untuk stres. ${ }^{9}$ Asupan gizi adalah salah satu indikator penentu status gizi yang dapat diukur melalui status antropometri.

Kekurangan gizi masih merupakan masalah kesehatan di Indonesia. Berdasarkan Riset Kesehatan Dasar (RISKESDAS) 2013 prevalensi pendek (menurut TB/U) pada anak remaja umur 13-15 tahun adalah 35,1\%, terdiri dari $13,8 \%$ sangat kurus dan $21,3 \%$ kurus. Sementara prevalensi kurus (IMT/U) pada anak remaja umur 13-15 tahun sebesar 10,8\%, terdiri dari 7,8\% kurus dan 3,3\% sangat kurus. Sulawesi Utara menempati posisi kelima setelah Bangka Belitung, Kepulauan Riau, DKI Jakarta, dan Bali untuk prevalensi kurus terendah di Indonesia. $^{10}$

Penelitian pada remaja-remaja putri di Semarang tahun 2011 didapatkan status gizi dalam batas yang normal dan kadar $\mathrm{Hb}$ yang berada di atas normal. Pada penelitian ini pula didapatkan tidak ada hubungan yang bermakna antara IMT dengan Hemoglobin. ${ }^{11}$ Hasil itu serupa dengan 
studi yang dilakukan oleh Zamzam A, dkk di Kuwait. ${ }^{11,12}$

Variasi makanan yang begitu banyak, membuat seorang anak hanya menyukai beberapa jenis makanan yang ada. Ada yang hanya menyukai daging, ada pula yang menyukai ikan, bahkan ada yang tidak menyukai sayur-sayuran. Hal ini dapat dilihat dari status gizi di Indonesia yang masih rendah, sehingga melatarbelakangi peneliti untuk melakukan penelitian mengenai hubungan antara status gizi dengan kadar hemoglobin pada anak usia 12-14 tahun.

\section{METODE PENELITIAN}

Penelitian yang dilakukan adalah penelitian dengan metode analitik dengan pendekatan secara potong lintang (cross sectional) dengan menggunakan data primer. Penelitian dilakukan pada bulan November - Desember 2014, dan tempat penelitian dilakukan di SMP Katolik Frater Don Bosco Manado dan Laboratorium Hematologi Ilmu Penyakit Dalam RSUP Prof R. D. Kandou Malalayang Manado. Cara pembuatan penelitian ini dengan hasil penelitian. Pengambilan sampel dilakukan di SMP Katolik Frater Don Bosco Manado dengan menggunakan timbangan berat badan untuk mengukur berat badan, microtoise untuk mengukur tinggi badan, dan mengambil sampel darah dengan disposable spuit 3 cc yang selanjutnya diperiksa kadar $\mathrm{Hb}$ dengan metode $\mathrm{Hb}$ Sahli di Laboratorium Hematologi Ilmu Penyakit Dalam RSUP Prof. R. D. Kandou Malalayang Manado. Pengolahan data dilakukan secara manual dengan menggunakan laptop dan pengkajian data dalam bentuk tulisan dan tabel distribusi frekuensi. Objek penelitian dalam hal ini adalah remaja usia 12-14 tahun dengan memakai variabel penelitian status gizi (IMT/U) dan hemoglobin. Data yang diperoleh, ditabulasikan menurut variabel penelitian yaitu: status gizi dan kadar hemoglobin.

\section{HASIL PENELITIAN}

Responden penelitian ini yaitu SiswaSiswi SMP Katolik Frater Don Bosco Manado yang berjumlah 45 orang.
Berdasarkan jenis kelamin, responden lakilaki sebanyak 19 responden (42.2\%) dan perempuan sebanyak 26 responden (57.8\%). Berdasarkan umur, responden yang berumur 12 tahun memiliki distribusi terbanyak yaitu sebanyak 24 responden (53.3), sedangkan yang berumur 14 tahun memiliki distribusi terendah yaitu sebanyak 3 responden (6.7\%). Hasil penelitian ini digambarkan bahwa status gizi normal memiliki distribusi tertinggi pada penelitian ini yaitu sebanyak 22 responden (48.9\%). Status gizi kurang dan sangat kurang memiliki distribusi terendah yaitu sebanyak 0 responden (0\%). Kadar hemoglobin responden yang normal memiliki distribusi tertinggi yaitu sebesar 37 responden (82.2\%).

Hasil penelitian dari keseluruhan responden digambarkan bahwa jenis kelamin laki-laki maupun perempuan didominasi oleh status gizi normal yaitu laki-laki sebanyak 10 responden (52.6\%) dan perempuan sebanyak 12 responden (46.2\%). Berdasarkan umur, responden yang berumur 12 tahun memiliki status gizi normal terbanyak sebanyak 11 responden (45.8\%). Status gizi overweight terbanyak berada pada responden yang berumur 13 tahun sebanyak 7 responden (38.9\%), sedangkan obesitas terbanyak pada umur 12 tahun sebanyak 7 responden (29.2\%).

Hasil penelitian ini menunjukan bahwa jenis kelamin laki-laki nonanemis sebanyak 15 responden (78.9\%), anemis ringan sebanyak 3 responden (15.8\%), anemis sedang sebanyak 1 responden (5.3\%). Sedangkan jenis kelamin perempuan nonanemis sebanyak 22 responden (84.6\%), anemis ringan sebanyak 3 responden (11.5\%), anemis sedang sebanyak 1 responden (3.8\%). Berdasarkan umur, responden yang berumur 12 tahun memiliki distribusi terbanyak diantara umur responden yang lain, yaitu nonanemis sebanyak 18 responden (75\%), anemis ringan sebanyak 4 responden (16.7\%), anemis sedang sebanyak 2 responden (8.3\%). Distribusi status gizi terhadap kadar hemoglobin dapat dilihat pada tabel 11. Berdasarkan penelitian ini 
digambarkan bahwa status gizi overweight memiliki persentase nonanemis tertinggi yaitu sebanyak 11 responden (84.6\%). Sedangkan distribusi anemis sedang terbanyak terdapat pada status gizi normal sebanyak 2 responden (9.1\%).

\section{BAHASAN}

Penelitian ini memiliki jumlah sampel sebanyak 45 orang dengan distribusi jenis kelamin laki-laki $42.2 \%$ dan perempuan $57.8 \%$ (Gambar 1). Berdasarkan umur, responden 12 tahun memiliki distribusi tertinggi yaitu 53.3\% responden umur 14 tahun memiliki distribusi terendah yaitu $6.7 \%$

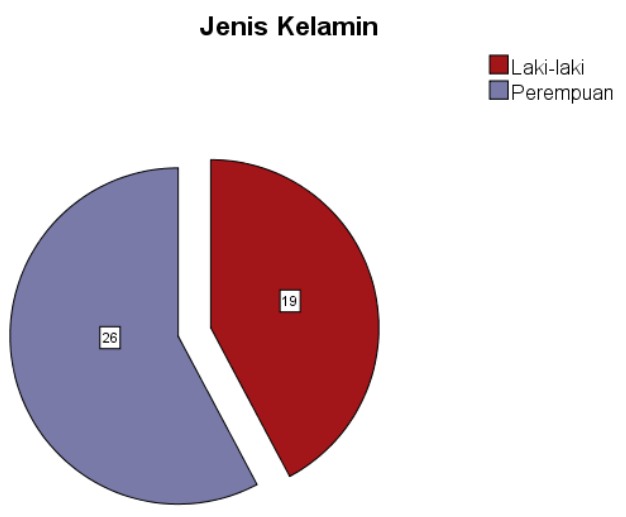

Gambar 1. Distribusi responden berdasarkan jenis kelamin

Status gizi normal memiliki distribusi tertinggi pada penelitian ini yaitu 48,9\% dan disusul status gizi overweight $28,9 \%$. Pada penelitian ini tidak didapatkan remaja dengan status gizi kurang dan sangat kurang. Status gizi obesitas memiliki distribusi sebanyak 22,2\%. Responden yang memiliki kadar hemoglobin normal memiliki distribusi tertinggi yaitu $82,2 \%$, sedangkan responden yang anemis ringan 13,3\% dan anemis sedang 4,4\%. Pada penelitian ini juga tidak didapatkan responden yang anemis berat.

Hasil penelitian ini menunjukan bahwa rerata tinggi badan sebesar 154,98 cm dengan standar deviasi 6,94. Terukur tinggi badan terendah yaitu $136 \mathrm{~cm}$ dan tertinggi yaitu $167 \mathrm{~cm}$. Rata-rata berat badan yaitu
53,26 kg dengan standar deviasi sebesar 12,52. Berat badan terendah yang terukur adalah 29,9 $\mathrm{kg}$ sementara yang tertinggi ialah 81,4 kg. Sementara IMT yang diukur lewat rumus berat badan dibahagi tinggi badan kuadrat memiliki rata-rata sebesar $22,11 \mathrm{~kg} / \mathrm{m}^{2}$, standar deviasi 4,65, terendah $15,2 \mathrm{~kg} / \mathrm{m}^{2}$, dan tertinggi sebesar 33,9 $\mathrm{kg} / \mathrm{m}^{2}$.

Pada penelitian ini juga menunjukan sebagian besar responden memiliki status gizi normal baik laki-laki maupun perempuan dimana laki-laki sebesar 52,6\% dan perempuan sebesar 46,2\% (Gambar 2).

Hasil penelitian ini sama dengan hasil penelitian yang dilakukan Yuniar R dan Fitrah E (2010) pada anak remaja SMP di Bogor yang menunjukan bahwa sebagian besar responden memiliki status gizi normal yaitu $83 \%$. $^{33}$

Hasil serupa juga ditemukan pada penelitian yang dilakukan Sorongan CI (2010) pada SMP Katolik Frater Don Bosco Manado pada tahun 2012 yang menunjukan tidak adanya responden dengan status gizi kurang maupun sangat kurang. Terdapat perbedaan antara penelitian ini dengan penelitian tersebut, dimana pada penelitian tersebut didapatkan status gizi obesitas memiliki distribusi terbanyak. ${ }^{13}$

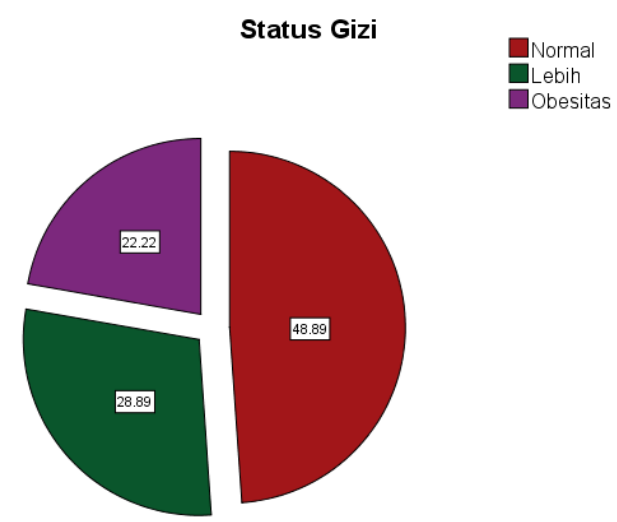

Gambar 2. Persentase status gizi responden

Hasil rata-rata kadar hemoglobin seluruh responden yaitu 13,08 g/dL dengan nilai standar deviasi yaitu 1,31. Kadar hemoglobin terendah yaitu 10,2 g/dL, sedangkan yang tertinggi ialah 16,2 g/dL. 
Hasil penelitian ini menunjukan, responden nonanemis terbanyak pada jenis kelamin perempuan sementara responden yang anemis ringan maupun sedang terbanyak pada jenis kelamin laki-laki. Responden laki-laki yang nonanemis sebesar 78,9\%, anemis ringan 15,8\%, dan anemis sedang sebesar 5,3\%. Pada perempuan, nonanemis sebesar 84,6\%, anemis ringan $11,5 \%$, dan anemis sedang $3,8 \%$.

Responden yang nonanemis terbanyak pada umur 14 tahun sebesar 100\%. Berbeda dengan anemis ringan dan sedang, terbanyak pada responden yang berumur 12 tahun, dimana anemis ringan sebesar 16,7\% dan anemis sedang sebesar 8,3\% (Gambar 3). Pada penelitian ini tidak didapatkan responden yang anemis berat. Hasil serupa juga ditemukan Manampiring A (2008) dalam penelitiannya di desa Minaesa didapatkan 60,58\% responden normal dan $39,42 \%$ responden anemis. ${ }^{14}$ Meskipun pada penelitian ini $82,2 \%$ responden nonanemis, namun ditemukannya $4,4 \%$ responden yang anemis sedang. Hal ini dapat menjadi tantangan baru bagi pertanda bahwa kesadaran masyarakat terlebih orang tua anak belum sepenuhnya menyadari akan pentingnya kesehatan.

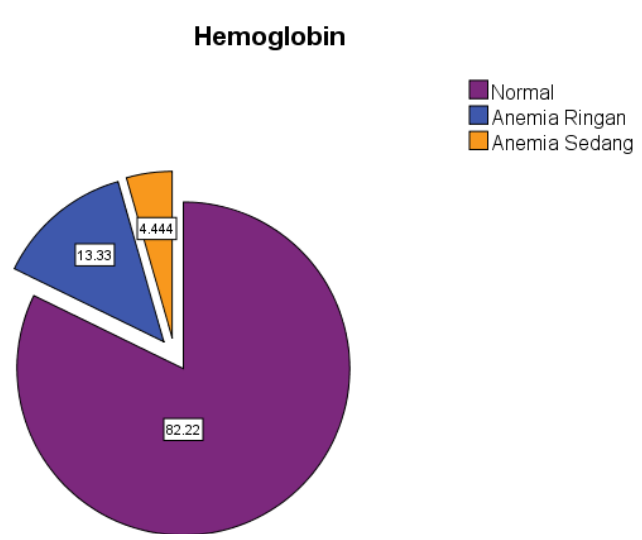

Gambar 3. Persentase nilai hemoglobin responden

Pengukuran antropometri adalah pengukuran secara langsung yang paling sering digunakan sebagai metode penilaian status gizi dan merupakan refleksi status sosial dan ekonomi suatu populasi. ${ }^{15,16}$ Status gizi adalah efek atau keadaan tubuh sebagai akibat konsumsi makanan serta penggunaan zat-zat gizi. ${ }^{17}$ Zat gizi juga berpengaruh terhadap sintesis hemoglobin. $^{18}$

Pada penelitian ini, melalui uji statistik dengan menggunakan program SPSS 20, hubungan antara status gizi dengan kadar hemoglobin memiliki nilai koefisien korelasi sebesar 0,145 dan nilai $\mathrm{p}=0,343>$ $\alpha=0,05$. Hal ini menunjukan pada penelitian ini tidak adanya hubungan antara status gizi dengan kadar hemoglobin. Hal ini berbeda dengan yang didapatkan oleh Wibowo CDT, Notoatmojo H, Rohmani A, di Semarang pada tahun 2010. ${ }^{19}$

Perbedaan hasil dengan penelitian yang sama kemungkinan disebabkan karena perbedaan skala variable penelitian. Pada penelitian ini, digunakan uji statistik Pearson Correlation, sementara pada penelitian oleh Wibowo CDT, dkk, menggunakan uji statistik Chi Square. Adapun pada penelitian ini tidak didapatkan data dengan status gizi kurang maupun sangat kurang, sehingga menyebabkan hasil dari penelitian ini ialah tidak adanya hubungan antar dua variabel yang diteliti.

\section{SIMPULAN}

Dari hasil penelitian mengenai hubungan antara status gizi dengan kadar hemoglobin pada remaja usia 12-14 tahun diperoleh kesimpulan sebagai berikut:

1. Tidak adanya hubungan antara status gizi dengan kadar hemoglobin pada remaja usia 12-14 tahun

2. Kadar hemoglobin secara umum pada remaja usia 12-14 tahun di SMP Katolik Frater Don Bosco Manado adalah normal.

3. Status gizi secara umum pada remaja usia 12-14 tahun di SMP Katolik Frater Don Bosco Manado adalah normal.

4. Ditemukannya remaja dengan anemis sedang menunjukan belum maksimalnya pencapaian promosi kesehatan kepada masyarakat 
terutama orang tua serta kesadaran dari masyarakat akan promosi kesehatan masih belum maksimal di kota Manado terutama di SMP Katolik Frater Don Bosco Manado.

5. Tidak ditemukannya remaja dengan status gizi kurang atau sangat kurang, mengindikasikan bahwa status gizi remaja di Manado terutama di SMP Katolik Frater Don Bosco Manado adalah baik.

\section{SARAN}

1. Memperbesar jumlah sampel untuk penelitian yang serupa

2. Menambah variabel penelitian seperti: asupan gizi, kadar ferritin, waist-hip-ratio

3. Perlu perhatian lebih kepada mereka yang ditemukan anemis

4. Memperbaiki pola makan dari mereka yang ditemukan overweight maupun obesitas.

5. Perlu ditingkatkan hal-hal yang menyangkut promosi kesehatan dan pencegahan dari segi ilmu gizi.

\section{DAFTAR PUSTAKA}

1. Gersten $T$, Wellington FL, editors. Hemoglobin. U.S. National Library of Medicine [Serial Online]. 2014. Diakses tanggal: 14 September 2014 URL:

http://www.nlm.nih.gov/medlineplus/ ency/article/003645.htm

2. Abdoerrachman MH, Affandi MB, Agusman S, Alatas H, Dahlan A, Bakry F, dkk; Buku Kuliah Ilmu Kesehatan Anak; vol II; Bagian Ilmu Kesehatan Anak Fakultas Kedokteran Universitas Indonesia; Jakarta; 1985

3. WHO, CDC. Worldwide Prevalence of Anaemia 1993-2005. World Health Organization; Geneva, 2008. h. 7-13

4. Anemia Defisiensi Besi pada Bayi dan Anak. IDAI [serial online]. 2013 diakses pada: 14 September 2014 URL: http://idai.or.id/public articles/seputar-kesehatan-anak

5. UNICEF. Early Childhood Development. UNICEF. New York. Diakses pada 14 September 2014 URL: www.univef.org/dprk/ec.pdf
6. Burklow KA, Phelps AN, Schultz JR, McConnell K, Rudolph C. Classifying Complex Pediatric Feeding Disorders. Journal of Pediatri Gastroenterology and Nutrition [serial online]. 1998. Diakses tanggal 15 September 2014 URL: http://www.ncbi.nlm.nih.gov/pubmed /9702643

7. Bernard AC. Feeding disorders in infants and toddlers. Canadian Family Physician. 2006 p.1247-51.

8. Stevenson RD. Feeding and nutrition in children with developmental disabilities. Pediatr Ann 1995. p.25560.

9. Behrman RE, Kliegman R, Arvin AM. Nelson Ilmu Kesehatan Anak. Ed. I. EGC: Jakarta;VI;43;178

10.Badan Penelitian dan Pengembangan Kesehatan Kementrian Kesehatan RI. Laporan Hasil Riset Kesehatan Dasar (RISKESDAS) Nasional 2013. Jakarta: Kementrian Kesehatan RI. 2013. h.216-22

11. Adhisti AP. Hubungan Status Antropometri dan Asupan Gizi Dengan Kadar HB dan Ferritin Remaja Putri. Fakultas Kedokteran Universitas Diponegoro Semarang; 2011. h. 5-8

12.A Mousa Z, Prakash P, Jackson RT, Al Raqua M. A Comparison of selected nutrient intakes in anemic and nonanemic adolescent girls in Kuwait. Nutrition Research. [serial online]. 2003;23:425-33

13.Sorongan CI. Hubungan Antara Aktivitas Fisik dengan Status Gizi Pelajar SMP Frater Don Bosco Manado. Manado: FKM; 2012. h.3

14.Manampiring A. Prevalensi Anemia dan Tingkat Kecukupan Zat Besi Pada Anak Sekolah Dasar Di Desa Minaesa Kecamatan Wori Kabupaten Minahasa Utara. Manado: Fakultas Kedokteran Unsrat; 2008. V. h. 34-46

15.Hartriyanti Y, Triyanti. Penilaian Status Gizi. Dalam: Syafiq A, Setiarni A, Utari D, Achadi E, Fatmah, Kusharisupeni, editor. Gizi dan Kesehatan Masyarakat. Jakarta: Rajawali Pers; 2010. h.275-303

16.Supariasa IDN, Bakri B, Fajar I. Penilaian Status Gizi. Jakarta: EGC; 
Jurnal e-Clinic (eCl), Volume 3, Nomor 1, Januari-April 2015

2002. h.18-21,43-52,56-62

17.Almatsier S. Prinsip dasar ilmu gizi. Jakarta: Gramedia Pustaka Umum; 2010. H.3-13

18.Kotecha PV. Nutritional Anemia in Young Children with Focus on Asia and India. Indian Journal of Community Medicine. India, 2011 diakses tanggal 12 Januari 2015. URL: http://www.ncbi.nlm.nih.gov/pmc/arti
cles/PMC3104701/?report=printable

19. Wibowo CDT, Notoatmojo H, Rohmani

A. Hubungan Antara Status Gizi dengan Anemia pada Remaja Putri di Sekolah Menengah Pertama Muhammadiyah 3 Semarang. Semarang: FK Universitas Muhammadiyah Semarang; 2013. h. 3-4. 